\title{
Pengaruh DAR, WCTO, NPM, Dan Pertumbuhan Penjualan Terhadap Nilai Perusahaan Food And Beverage
}

\author{
Sinthia Anggi Sitepu' ${ }^{1}$, Meriana Situmorang², Mei Linda Siregar³ ${ }^{3}$ Marice Habeahan ${ }^{4}$, \\ Jelita Bakara ${ }^{5}$
}

1,2,3,4,5 Fakultas Ekonomi,Universitas Prima Indonesia

E-mail : anggisinthia@gmail.com

Direvisi: 29 Mei 2019 Dipublikasikan: 30 Juni 2019

\begin{abstract}
Abstrak
Besar kecilnya nilai perusahaan dapat diukur melalui harga saham. Semakin tinggi harga saham maka akan semakin tinggi pula keuntungan yang didapatkan oleh perusahaan. Penelitian ini bertujuan untuk menguji pengaruh debt to asset ratio, working capital turnover, net profit margin, dan Pertumbuhan Penjualan terhadap nilai perusahaan pada perusahaan Food and Beverage yang terdaftar di Bursa Efek Indonesia tahun 2012- 2017. Model analisis yang digunakan adalah regresi berganda.Populsi penelitian ini adalah 21 perusahaan dengan sampel 12 perusahaan.Teknik pengambilan sampel ini menggunakan purposive sumpling.Hasil penelitian ini menunjukkan secara simultan debt to asset ratio, working capital turnover, net profit margin, dan Pertumbuhan Penjualan berpengaruh tidak signifikan terhadap nilai perusahaan. Sedangkan debt to asset ratio secara parsial berpengaruh tidak signifikan, working capital turnover, secara parsial berpengaruh tidak signifikan, net profit margin secara parsial berpengaruh signifikan dan Pertumbuhan Penjualan secara parsial berpengaruh tidak signifikan.
\end{abstract}

Kata Kunci : Debt To Asset Ratio, Working Capital Turnover, Net Profit Margin, Pertumbuhan Penjualan, Nilai Perusahaan.

\begin{abstract}
The size of the company's value can be measured through stock prices. The higher the stock price, the higher the profit gained by the company. This study aims to examine the effect of debt to asset ratio, working capital turnover, net profit margin, and Sales Growth on company value on Food and Beverage companies listed on the Indonesia Stock Exchange in 2012-2017. The analysis model used is multiple regression. The population of this study was 21 companies with a sample of 12 companies. This sampling technique uses purposive sumpling. The results of this study indicate simultaneously debt to asset ratio, working capital turnover, net profit margin, and Sales Growth have no significant effect on firm value. While partially debt to asset ratio has no significant effect, working capital turnover partially has no significant effect, net profit margin partially has a significant effect and Sales Growth partially has no significant effect.
\end{abstract}

Keywords: Debt To Asset Ratio, Working Capital Turnover, Net Profit Margin, Sales Growth, and Company Value 


\section{Sentralisasi Volume 8 (2) Hal : 77 - 85 | 2019}

Pengaruh DAR, WCTO, NPM, Dan Pertumbuhan Penjualan...

Doi (https://doi.org/10.33506/sl.v8i2.427)

Sinthia Anggi Sitepu

\section{Pendahuluan}

Sejalan dengan perkembangan perekonomian, banyak perusahaan yang melakukan ekspansi usaha. Pemenuhan kebutuhan dana perusahaan dapat diperoleh dengan melakukan pinjaman dalam bentuk utang atau menerbitkan saham dipasar modal berarti bahwa perusahaan bukan hanya dimiliki oleh pemilik lama tetapi juga dimiliki masyarakat. Perusahaan yang mampu menggunakan utang dengan secara efektif akan menghasilkan nilai tambah atau keuntungan bagi perusahaan maupun pihak investor. Untuk memahami kondisi keuangan diperlukan analisis terhadap laporan keuangan perusahaan. Kemajuan perusahaan akan seiring dengan modal yang diperlukan untuk membiayai kegiatan usahanya. Semakin besar perusahaan akan semakin besar pula modal yang diperlukan untuk membiayai kegiatan usahanya. Tingkat perputaran modal kerja menjadi aspek penting bagi tiap perusahaan karena modal kerja merupakan faktor penentu berjalannya kegiatan operasional jangka pendek dalam perusahaan yang berpengaruh pada pendapatan yang diperoleh perusahaan dan besarnya deviden yang akan dibagikan kepada para pemegang saham.

Sebelum menanamkan dananya, investor melakukan analisis terhadap kemampuan perusahaan untuk menghasilkan laba.Mereka berkepentingan atas informasi yang berhubungan dengan kondisi keuangan yang berdampak pada kemampuan perusahaan untuk membayar dividen untuk menghindari kebangkrutan. Oleh karena itu, investor hanya akan menginvestasikan dananya kepada perusahaan yang mempunyai reputasi baik. Perusahaan yang mempunyai reputasi baik adalah perusahaan yang mampu memberikan dividen secara konstan kepada pemegang saham. Keberhasilan suatu usaha juga dilihat dari volume penjualan yang didapat. Dengan kata lain, apakah perusahaan itu dapat mendapatkan laba atau tidak sangat bergantung pada keberhasilan penjualan. Dengan tingkat penjualan yang tinggi, perusahaan dapat meraih keuntungan yang optimal.Dimana keuntungan dan kepuasan pelanggan merupakan ukuran penilaian dari keberhasilan suatu perusahaan dan keberlangsungan hidup perusahaan.Penjualan menjadi sebuah hal yang sangat penting bagi perusahaan, sebab nilai keuntungan dan kerugian yang diperoleh dari aktivitas penjualan menjadi sumber yang membentuk nilai keseluruhan perusahaan.

Nilai perusahaan dapat mencerminkan nilai aset yang dimiliki perusahaan seperti surat - surat berharga. Saham merupakan salah satu surat berharga yang dikeluarkan oleh 


\section{Sentralisasi Volume 8 (2) Hal : 77 - 85 | 2019}

Pengaruh DAR, WCTO, NPM, Dan Pertumbuhan Penjualan...

Doi (https://doi.org/10.33506/sl.v8i2.427)

Sinthia Anggi Sitepu

perusahaan, tinggi rendahnya harga saham banyak dipengaruhi oleh kondisi emiten. Nilai perusahaan merupakan presepsi investor terhadap tingkat keberhasilan perusahaan yang sering dikaitkan dengan harga saham.Kekayaan pemegang saham dipresentasikan oleh harga pasar dari saham yang merupakan cerminan dari keputusan investasi, pendanaan dan manajemen asset. Menurut Sunyoto (2013 : 108), Debt to Asset Ratio merupakan rasio yang menunjukkan besarnya biaya total aktiva yang pembiayaannya berasal dari total utang. Semakin tinggi rasio ini berarti semakin besar jumlah pinjaman yang digunakan untuk membiayai aktiva perusahaan. Menurut Kasmir (2012 : 156), Debt to Asset Ratio merupakan rasio utang yang digunakan untuk mengukur perbandingan antara total utang dengan total aktiva. Dengan kata lain, seberapa besar aktiva perusahaan dibiayai oleh utang atau seberapa besar utang perusahaan berpengaruh terhadap pengelolaan aktiva. Jumingan (2014 : 132), Working Capital Turnover merupakan rasio antara penjualan dengan modal kerja. Working Capital Turnover menunjukkan jumlah rupiah penjualan neto yang diperoleh bagi setiap rupiah modal kerja. Menurut Hery (2015 : 218), Working Capital Turnover merupakan rasio yang digunakan untuk mengukur keefektifan modal kerja (aset lancar) yang dimiliki perusahaan dalam menghasilkan penjualan. Rasio ini dihitung sebagai hasil bagi antara besarnya penjualan (tunai maupun kredit) dengan rata-rata aset lancar.

Menurut Harahap (2015 : 304), Marjin laba bersih merupakan rasio yang menunjukkan seberapa besar persentase pendapatan bersih yang diperoleh dari setiap penjualan. Menurut Kodrat (2010 : 240), Marjin laba bersihmerupakan rasio yang digunakan untuk menghitung sejauh mana kemampuan perusahaan menghasilkan laba bersih pada tingkat penjualan tertentu. Harahap (2015 : 309), Pertumbuhan penjualan merupakan rasio yang menunjukkan persentasi kenaikan penjualan tahun ini dibanding tahun lalu. Semakin tinggi rasio ini maka semakin baik. Menurut Subramanyam \& John (2010 : 72), Pertumbuhan penjualan merupakan analisis tren penjualan berdasarkan segmen berguna dalam menilai profitabilitas. Harmono (2009 : 233), Nilai perusahaan merupakan kinerja perusahaan yang dicerminkan oleh harga saham yang dibentuk oleh permintaan dan penawaran di pasar modal yang merefleksikan penilaian masyarakat terhadap kinerja perusahaan. Menurut Utari, Purwanti \& Prawironegoro (2014 : 305), Nilai perusahaan adalah laba bersih setelah pajak atau net operating profit after tax dibagi biaya modal rata-rata tertimbang. 
Sentralisasi Volume 8 ( 2 ) Hal : 77 - 85 | 2019

Pengaruh DAR, WCTO, NPM, Dan Pertumbuhan Penjualan...

Doi (https://doi.org/10.33506/sl.v8i2.427)

Sinthia Anggi Sitepu

\section{Metode Penelitian}

Pendekatan penelitian ini adalah penelitian kuantitatif.Jenis penelitian yang digunakan peneliti adalah penelitian deskriptif.Sifat penelitian yang digunakan dalam penelitian ini adalah bersifat hubungan kausal.Populasi yang digunakan dalam penelitian ini adalah seluruh perusahaan Food and Beverage yang terdaftar di Bursa Efek Indonesia Tahun 2012-2017 yang berjumlah 21 perusahaan.Penarikan sampel dilakukan dengan purposive sampling method.Sampel perusahaan sebanyak 12 perusahaan memiliki kriteria tertentu diuraikan pada sebagai berikut : 1) Perusahaan Food and Beverage yang terdaftar di Bursa Efek Indonesia tahun 2012-2017. 2) Perusahaan Food and Beverage yang tidak menerbitkan laporan keuangan secara lengkap tahun 2012-2017. 3) Perusahaan Food and Beverage yang mengalami kerugian tahun 2012-2017.

Teknik pengambilan data dalam penelitian ini dilakukan melalui studi dokumentasi yaitu dengan cara menganalisa laporan keuangan perusahaan food and beverage yang terdaftar di Bursa Efek Indonesia tahun 2012-2017 melalui situs resmi www.idx.co.id._Jenis data ini merupakan data sekunder yaitu data penelitian yang diperoleh secara tidak langsung melalui media perantara.

\section{HASIL DAN PEMBAHASAN}

Tabel 1 Hasil Statistik Deskriptif

\begin{tabular}{|l|r|r|r|r|r|}
\hline \multicolumn{1}{|c|}{ Variabel } & N & \multicolumn{1}{c|}{ Minimum } & \multicolumn{1}{c|}{ Maximum } & \multicolumn{1}{c|}{ Mean } & \multicolumn{1}{c|}{ Std. Deviation } \\
\hline X1 & 72 & 51.177 .600 .000 & 77.667 .432 .700 .000 & 4.285 .111 .816 .111 .110 & 20.876 .325 .708 .252 .600 \\
X2 & 72 & -881.393 .157 .200 .000 & 832.236 .651 .500 .000 & 23.247 .603 .278 .055 .500 & 338.810 .571 .717 .660 .000 \\
X3 & 72 & 92.520 .400 .000 & 39.002 .063 .900 .000 & 917.452 .469 .027 .778 & 9.427 .644 .286 .695 .170 \\
X4 & 72 & -99.999 .893 .400 .000 & 653.614 .436 .400 .000 & 2.986 .843 .050 .277 .770 & 104.450 .684 .071 .897 .000 \\
NilaiPerusahaan & 72 & 288.000 .000 & 899.406 .827 .300 .000 & 32.392 .086 .398 .888 .800 & 225.775 .879 .037 .649 .000 \\
Valid N (listwise) & 72 & & & & \\
\hline
\end{tabular}

Dari tabel diatas dapat disimpulkan bahwa : 1) Variabel DAR memiliki jumlah sampel 72. Nilai minimum sebesar 511776.00000, nilai maximum sebesar 776674327.00000 dan nilai std.deviation adalah sebesar 208763257.08252653. 2) Variabel WCTO memiliki jumlah sampel 72. Nilai minimum sebesar -8813931572.00000 , nilai maximum sebesar 8322366515.00000 dan nilai std.deviation adalah sebesar 3388105717.17660860. 3) Variabel 
NPM memiliki jumlah sampel 72. Nilai minimum sebesar 925204.00000, nilai maximum sebesar 390020639.00000 dan nilai std.deviation adalah sebesar 94276442.86695170. 4) Variabel Pertumbuhan Penjualan memiliki jumlah sampel 72. Nilai minimum sebesar 999998934.00000, nilai maximum sebesar 6536144364.00000 dan nilai std.deviation adalah sebesar 1044506840.71897390. 5) Variabel NIlai Perusahaan memiliki jumlah sampel 72. Nilai minimum sebesar 2880.00000, nilai maximum sebesar 8994068273.00000 dan nilai std.deviation adalah sebesar 2257758790.37649540.

\section{Uji Asumsi Klasik}

Tabel 2 Hasil Uji One-Sample Kolmogorov-Smirnov Test

\begin{tabular}{|c|c|c|}
\hline \multicolumn{2}{|c|}{ Keterangan } & Unstandardized Residual \\
\hline$N$ & & 72 \\
\hline \multirow{2}{*}{ Normal Parameters ${ }^{a, b}$} & Mean & 0000001 \\
\hline & Std. Deviation & 2112227278.48378370 \\
\hline \multirow[t]{3}{*}{ Most Extreme Differences } & Absolute & .098 \\
\hline & Positive & .098 \\
\hline & Negative & -.096 \\
\hline Test Statistic & & .098 \\
\hline Asymp. Sig. (2-tailed) & & $.081^{\mathrm{c}}$ \\
\hline
\end{tabular}

Hasil menunjukkan nilai signifikansi pada uji kolmogorov smirnov diatas 0,05 . Artinya data terdistribusi normal, dan dapat dilanjutkan dengan uji asumsi klasik lainnya.

Tabel 3 Hasil Uji Multikolinieritas

\begin{tabular}{|c|c|c|}
\hline \multirow[b]{2}{*}{ Model } & \multicolumn{2}{|c|}{ Collinearity Statistics } \\
\hline & Tolerance & $V I F$ \\
\hline \multicolumn{3}{|l|}{ (Constant) } \\
\hline DAR & .917 & 1.091 \\
\hline WCTO & .840 & 1.191 \\
\hline Net Profit Margin & .845 & 1.183 \\
\hline Pertumbuhan Penjualan & .980 & 1.020 \\
\hline
\end{tabular}


Sentralisasi Volume 8 (2) Hal : 77 - $85 \mid 2019$

Pengaruh DAR, WCTO, NPM, Dan Pertumbuhan Penjualan...

Doi (https://doi.org/10.33506/sl.v8i2.427)

Sinthia Anggi Sitepu

Nilai VIF dari DAR, WCTO, NPM, dan Pertumbuhan Penjualan adalah lebih dari 10 dan dapat disimpulkan tidak terjadi multikolinieritas.

Tabel 4 Hasil Uji Autokolerasi

\begin{tabular}{ccc}
\hline Durbin Watson & $\mathbf{d u}<\mathbf{D W}<\mathbf{4 - d u}$ & Interpretasi \\
\hline 2,170 & $1,735<2,170<2,265$ & Tidak terjadi autokorelasi \\
\hline
\end{tabular}

Setelah dilakukan uji multikolinieritas maka dilanjutkan dengan uji autokorelasi. Untuk melihat terjadinya autokorelasi dapat dilihat melalui ketentuan $\mathrm{du}<\mathrm{dw}<4-\mathrm{du}$ atau $1,735<2,170<4-1,735=1,735<2,170<2,265$ maka dapat disimpulkan tidak terjadi autokorelasi.

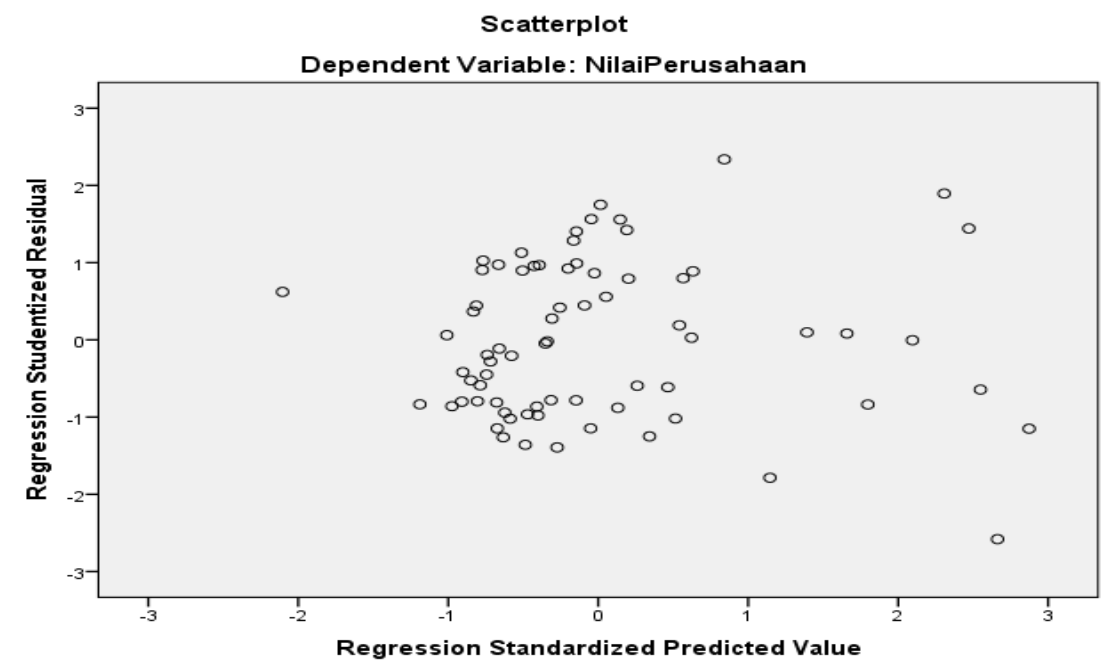

Gambar 1. Scatterplot

Uji Heteroskedastisitas dengan menggunakan grafik scatterplot memperlihatkan bahwa titik-titik tampak menyebar diatas dan dibawah angka 0 pada sumbu $\mathrm{Y}$ dan tidak menggambarkan suatu pola tertentu. Maka dapat disimpulkan bahwa model tidak mengalami heteroskedastisitas. 
Sentralisasi Volume 8 ( 2 ) Hal : 77 - 85 | 2019

Pengaruh DAR, WCTO, NPM, Dan Pertumbuhan Penjualan...

Doi (https://doi.org/10.33506/sl.v8i2.427)

Sinthia Anggi Sitepu

\section{Uji Hipotesis}

Tabel 5 Uji Hipotesis

\begin{tabular}{|c|c|c|c|c|c|}
\hline Model & $\begin{array}{c}\text { Unstandardized } \\
\text { B } \\
\end{array}$ & $\begin{array}{l}\text { Coefficients } \\
\text { Std. Error }\end{array}$ & $\begin{array}{c}\text { Standardized } \\
\text { Coefficients } \\
\text { Beta }\end{array}$ & $\mathbf{t}$ & Sig. \\
\hline (Constant) & 3042949327 & 798532604 & & 3.811 & .000 \\
\hline DAR & -.932 & 1.291 & -.086 & -.722 & .473 \\
\hline WCTO & -.009 & .083 & -.013 & -.102 & .919 \\
\hline NPM & 7.309 & 2.977 & .305 & 2.455 & .017 \\
\hline PertumbuhanPenjualan & -.185 & .250 & -.086 & -.742 & .461 \\
\hline
\end{tabular}

Dari tabel uji t dapat disimpulkan bahwa DAR, WCTO, dan Pertumbuhan Penjualan tidak berpengaruh signifikan sedangkan NPM berpengaruh positif dan signifikan. Berdasarkan hasil analisis bahwa DAR secara parsial berpengaruh tidak signifikan terhadap nilai perusahaan. Menurut Kamaludin dan Indrinai (2012:321) bahwa kenaikan nilai perusahaan terjadi karena pembayaran bunga atas hutang merupakan pengurangan pajak oleh Karena itu laba operasi yang diterima investor akan lebih besar. Dampak selanjutnya karena laba yang diterima lebih besar, nilai perusahaan juga akan lebih besar. Hasil penelitian ini tidak mendukung dari peneliti sebelumnya Made dan Agung (2016) bahwa DAR berpengaruh positif terhadap nilai perusahaan.

Variabel WCTO juga secara parsial tidak berpengaruh signifikan terhadap nilai perusahaan. Menurut Fahmi (2015:103) bahwa semakin besar perusahaan maka kebutuhan dana untuk menunjang modal kerja juga semakin tinggi, dan itu diikuti juga dengan harus semakin tinggin perputaran yang bisa diberikan agar tertutupinya biaya modal kerja yang telah dikeluarkan. Secara konsep ketika turnover penjualan semakin tinggi serta melewati batas biaya modal kerja yang dikeluarkan maka artinya perusahaan akan memperoleh keuntungan (profit), dan begitu pula sebaliknya. Hasil penelitian ini mendukung dari penelitian sebelumnya Christiana dkk (2016) bahwa tidak adanya hubungan antara perputaran modal kerja dengan nilai perusahaan maka dapat disimpulkan bahwa apabila kecilnya perputaran modal kerja sebuah perushaan maka nilai saham perusahaan akan menurun sehingga akan menurunkan minat perusahaan untuk membeli saham perusahaan tersebut. 
Sentralisasi Volume 8 ( 2 ) Hal : 77 - 85 | 2019

Pengaruh DAR, WCTO, NPM, Dan Pertumbuhan Penjualan...

Doi (https://doi.org/10.33506/sl.v8i2.427)

Sinthia Anggi Sitepu

Sementara itu variabel NPM secara parsial justru berpengaruh signifikan terhadap nilai perusahaan.Menurut Hery (2014:199) bahwa semakin tinggi margin laba bersih berarti semakin tinggi pula laba bersih yang dihasilkan dari penjualan bersih.Hal ini dapat disebabkan karena tingginya laba sebelum pajak penghasilan.Sebaliknya semakin rendah margin laba bersih berarti semakin rendah pula laba bersih yang dihasilkan dari penjualan bersih.Hal ini dapat disebabkan karena rendahnya laba sebelum pajak penghasilan.Hasil penelitian dari penelitian sebelumnya Ferlen dkk (2015) menyatakan bahwa NPM tidak berpengaruh nilai perusahaan.

Variabel pertumbuhan penjualan secara parsial tidak berpengaruh signifikan terhadap nilai perusahaan.Menurut Sudana (2010:162) bahwa perusahaan yang tingkat pertumbuhan penjualannya relative tinggi dimungkinkan untuk dibelanjia dengan menggunakan utang yang lebih besar dibandingkan dengan perusahaan yang pertumbuhan penjualannya yang rendah, karena keuntungan yang diperoleh dari peningkatan penjualan tersebut diharapkan masih bisa menutupi biaya utang.Hasil penelitian ini bertentangan dengan peneliti sebelumnya Lita dkk (2016) bahwa pertumbuhan penjualan berpengaruh negative terhadap nilai perusahaan.

\section{Simpulan}

Secara keseluruhan dapat dilihat bahwa hanya variabel NPM saja yang berpengaruh signifikan terhadap nilai perusahaan, sementara ketiga variabel lainnya seperti DAR, WCTO, dan Pertumbuhan Penjualan tidak berpengaruh signifkan. Dengan kata lain perusahaan harus fokus pada peningkatan penjualan yang dapat menghasilkan laba untuk mendukung operasional perusahaan di sektor makanan dan minuman agar tetap bertahan yang nantinya dapat meningkatkan nilai perusahaan.

\section{Daftar Pustaka}

Christiana. Nangoy, Sintje. Saerang S, Ivonne.2016. Pengaruh Perputaran Modal Kerja dan Profitabilitas Terhadap Nilai Perusahaan Pada Perusahaan Farmasi di Bursa Efek Indonesia. Jurnal Berkala Ilmiah Efisiensi. (16).372-373.

Fahmi, Irham. 2014. Pengantar Manajemen Keuangan. Ed. 3, Bandung: CV Alfabeta Ferlen dkk Pengaruh Faktor Likuiditas,Leverage,NPM dan ROI Terhadap Nilai Perusahaan (Studi pada Perusahaan Consumer Goods yang Terdaftar di Bursa Efek Indonesia Periode 2010 - 2013).Jurnal EMBA. Juni (3).554-555. 
Harahap, Sofyan Syafri. 2015. Analisis Kritis Laporan Keuangan. Ed.12, Jakarta: PT Raja Grafindo Persada.

Harmono. 2009. Manajemen Keuangan. Ed.1, Jakarta: PT Bumi Aksara.

Hery. 2015. Analisa Laporan Keuangan. Ed.1, Yogyakarta: CAPS (Center for Academic Publishing Service).

Jumingan. 2014. Analisis Laporan Keuangan. Ed. 5, Jakarta: PT Sawo Raya.

Kamaludin, dan Indriani. 2012. Manajemen Keuangan. Bandung: CV Maju $\quad$ Mundur.

Kasmir.2012. Analisa Laporan Keuangan. Ed.8, Jakarta: PT RajaGrafindo Persada.

Kodrat dan Indonanjaya. 2010. Manajemen Investasi.Bandung: Alfabeta.

Lita, dkk.2016.Pengaruh Return on Asset,Debt to Equity dan Pertumbuhan Penjualan Terhadap Nilai Perusahaan Pada Sektor Real Estate dan Property yang Terdaftar di BEI Tahun 2013-2014 JurnalBerkala Ilmiah Efisiensi.(16).821-822.

Made \& Agung, Pengaruh Debt To Asset Ratio, Deviden Payout Ratio dan Return On Asset Terhadap Nilai Perusahaan. Vol. 17.3 Unud ( Bali Indonesia )

Subramanyam, dan John. 2010. Analisa Laporan Keuangan. Ed. 10, Jakarta: $\quad$ Salemba Empat.

Sudana, I made. 2011.Manajemen Keuangan Perusahaan Teori dan Praktik. Jakarta: Erlangga.

Sunyoto.2013.Dasar- dasar Manajemen Keuangan Perusahaan.Yogyakarta:Caps 2013.

Utari, Purwanti dan Prawironegoro. 2014. Manajemen Keuangan. Jakarta: Mitra Wacana Media. 